\title{
The Torigatayama Limestone Quarry
}

\author{
by Sansan SOMA
}

The Torigatayama limestone quarry is the most up to date and large scale quarry in Japan, located in Shikoku island, Kouchi prefecture. However the annual production capacity has been increased successively to $10 \mathrm{Mt}, 1983$ 's annual production rate fell sharply than its capacity due to the depressed state of the Japan economy.

The operation is separated into two locations, Niyodo village and Susaki city. The quarry and the primary crushing facilities are in Niyodo village, and the processing plant and the ship loading facilities are in Susaki city. Both processing plant and primary crushing facilities are connected by the long distant belt conveyor of $23 \mathrm{~km}$ long with the belt speed of $300 \mathrm{~m} / \mathrm{min}$, of which $92 \%$ is installed in the underground.

The Torigatayama quarry has adopted the bench cut with vertical shafts system. The quarrying area has been getting wider to $0.8 \mathrm{~km}^{2}$ now and the elevation of the top bench is $1340 \mathrm{~m}$ above sea level.

The production has started on May of 1970 after two years development work. Since then the accumulated production of $100 \mathrm{Mt}$ was achieved on Nov. of 1983 . Roughly speaking, $50 \%$ of the products are sent to the steel makers, $30 \%$ to the cement makers, $10 \%$ to the construction works and the rest of them are shipped abroad.

The limestone ore deposit is occurred in the Chichibu formation and it is covered by thin top soil of less than $1 \mathrm{~m}$ and has intercalation of the schalstein along the strike in the northern part of the ore deposit. The minable ore reserves are estimated around $1500 \mathrm{Mt}$.

The climatic conditions at the quarry site may be characterized by the thick fog in the spring and the early summer, the heavy rain fall of around $1500 \mathrm{~mm}$ monthly in the summer and the early autumn, and the cold weather of which temperature goes down sometimes $20^{\circ} \mathrm{C}$ below zero and the snow fall of more than $1 \mathrm{~m}$ deep in the winter.

The detailed description of the operations are given as follows.

[ 露天採掘 ]

\section{[3-7]武甲山協調採掘 ${ }^{\mathrm{a})}$}

\section{1. 緒}

石灰石は我が国唯一の豊富な地下資源であるが, 環境規制等の影 響もあり採掘可能鉱量は約 100 億 $\mathrm{t}$ といわれている。従つて, 現 在の生産ペースを続けると50６0年の鉱命に過ぎず，埋蔵する石 灰石を遺利なく採掘することが企業永続の道であり，国家的使命 でもある。

武甲山には，現在秩父セメント㑣三輪鉱山，菱光石灰工業(㑣宇

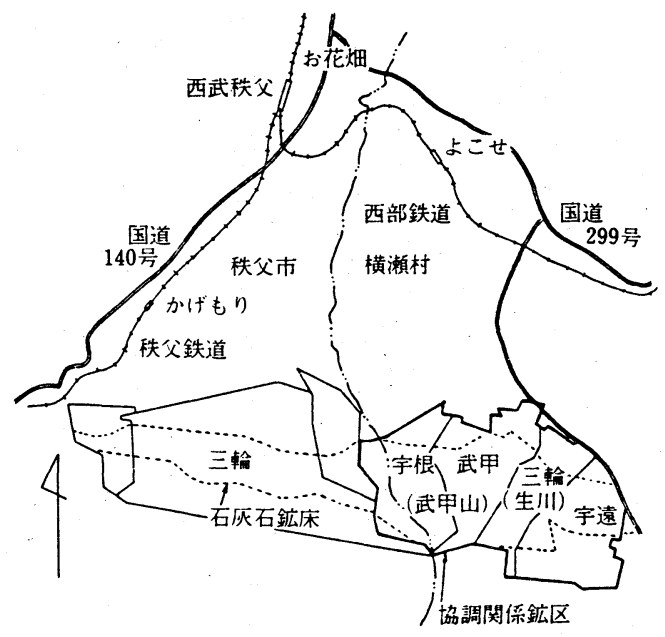

第 1 図 位置および鉱区図

1. 菱光石灰工業株式会社宇遠鉱山長

2. 菱光石灰工業株式会社宇根鉱山長

3. 武甲鉱業株式会社武甲鉱山長

4. 秩父セメント株式会社三輪鉱山長

a）昭和57年石灰石鉱業大会にて発表，石灰石鉱業協会誌「石灰石 57 年 7 月号に掲載済のものを，その後の経緯を追加訂正した。

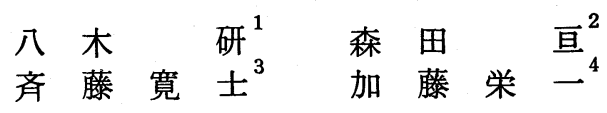

根鉱山・宇遠鉱山，武甲鉱業侏武甲鉱山の 3 社 4 鉱山（以下これ を「3 社」という) が稼行しているが, 石灰石の遺利なき採掘, 安全の確保並びに効果的環境保全対策等を実施し, 企業と地域の 共存共栄を図ることを目的として, 3 社は 3 社協調採掘を計画し, 56 年 4 月より開始した。

\section{2. 武甲山の位置, 交通}

武甲山は, 埼玉県西部の秩父盆地南東端に急峻な形で屹立して おり，古くから日本の名山として知られているばかりでなく，地 域の人々にとつて信仰の対象でもある。

交通は西武鉄道の終点西武秩父駅で下車，自動車で10１5分に て，山麓にある各事業所に着く(第 1 図)。

\section{3. 地 - 鉱床}

武甲山の石灰石鉱床は, 二畳紀の秩父古生層として知られてお り (最近三畳紀説もある), 東西約 $5 \mathrm{~km}$, 厚さ数百 $\mathrm{m}$ の規模で 賦存している。石灰石鉱床の一般走行はN $70^{\circ} \mathrm{W}$, 傾斜は $45 \sim 80^{\circ}$ $\mathrm{N}$ で，山頂付近の傾斜は緩く層状単斜構造をなしている。

下盤は輝緑凝灰岩層で, 上盤は上影森層と呼ばれている珪質石 灰岩層, チャート層, 粘板岩層, 砂岩層等からなつている (昭和 52 年度石灰石鉱業大会で詳細発表済)。

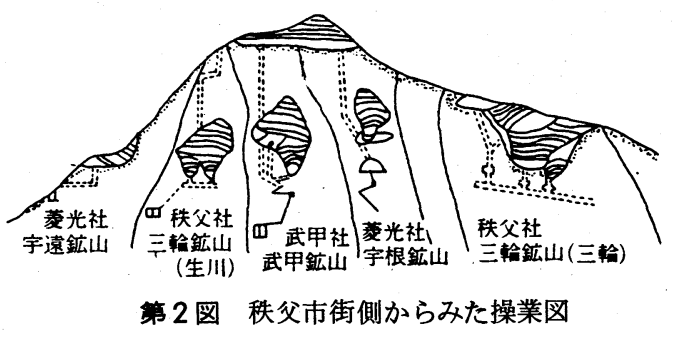

日本鉱業会誌/1001160（'84-10）1011<165> 
第 1表 操 業 状 況

\begin{tabular}{|c|c|c|c|c|c|c|}
\hline 会 & 社 名 & 菱光石灰工業 & 秩父セメント & 武甲鉱業 & 菱光石灰工業 & 秩父セメント \\
\hline \multirow{2}{*}{\multicolumn{2}{|c|}{ 鉱 山 名 }} & 宇遠鉱山 & 三輪鉣山 & 武甲鉱山 & 宇根鉱山 & 三輪鉱山 \\
\hline & & & 生川地区 & & & 三輪地区 \\
\hline \multicolumn{2}{|c|}{ 創 } & 1940年 & 1964年 & 1970年 & 1967年 & 1924年 \\
\hline \multicolumn{2}{|c|}{ 稼 働 人員 } & 38 人 & 2人 & 56 人 & 38 人 & 162 人 \\
\hline \multicolumn{2}{|c|}{ 生 産 量 } & 1,401 千 $\mathrm{t}$ & 240 千 $t$ & 3,256 千 $t$ & 1,587 千t & 4,310 千 $t$ \\
\hline \multirow{3}{*}{$\begin{array}{l}\text { 出 } \\
\text { 荷 } \\
\text { 生 }\end{array}$} & セメント & 933 千t & 240 千 $t$ & 2,020 千 $\mathrm{t}$ & 1,425 千 $\mathrm{t}$ & 4,310 千 $t$ \\
\hline & 灰 & 183 千 $\mathrm{t}$ & - & 703 千 $t$ & 162 千t & - \\
\hline & その他 & $285 千 \mathrm{t}$ & - & 440 千 $\mathrm{t}$ & - & - \\
\hline
\end{tabular}

b) 一方, 各社のベンチ面積, 石灰石採掘量 に違いがあるので, 必要に応じ石灰石の相互 供給を行う。

c ）採掘上必要な鉱山道路，坑道，用地等の 使用について，便宜供与をはかる。 d）環境保全に万全を期するための採掘跡地 の崩落防止, 緑化, 治水等の公害防止並びに 保安確保対策, 地元対策等について, 相互に 協力して対処する。

\section{$5 \cdot 4$ 最終残壁}

3 社は残壁問題の重要性に鑑み, 48 年11月 「秩父地区残壁研究会」を発足させ，残壁安

\section{4. 石灰石鉱山の操業状況}

武甲山の石灰石採掘は古く, 大正 6 年鉱床西端部で開始された。 戦後, セメント, 鉄鋼等の生産増大にともなつて, あいついで鉱 山が開設され, 現在 3 社 4 鉱山が操業しており, 年間 1,000 万〜 1,200 万 $\mathrm{t}$ の石灰石を採掘し, セメント, 石灰, 骨材, フィラー 用等に出荷している。

各社は40年代半ば頃までグローリホール法による採掘を行つて いたが, その後ベンチカット採掘法に移行している(第 2 図, 第 1 表)。

\section{5. 協調採掘の経緯}

\section{$5 \cdot 1$ 協調採掘以前の状況}

各鉱山は, 地形が急峻であるなどの理由から，中腹から採掘し ていたため, 埋蔵鉱量に比べ可採鉱量が著しく少なかつた。又, 各社の採掘ベンチ間は上下作業となり, 保安上好ましくなく, か つ, 採掘可能限界まで降下すると再び上位に移り採掘するため, 残壁の恒久的緑化は不可能であり，加えて裸の残壁が次第に拡大 するため, 自然環境保全上好ましくなかつた。更に, 昭和46年頃 から公害および自然環境破壊等に対する規制強化，並びに企業の 社会的責任に対する世論の高まり等々あり, 以上の状況に対応す るため, 3 社はそれぞれの対策に苦慮していた。

\section{$5 \cdot 2$ 基本構想}

3 社は, 貴重な石灰石資源を遺利なく採掘し，より長期に安定 した操業を行ない，又，環境保全に対し有効な方法を実施し，地 域社会の繁栄に寄与し, 企業と地域の共存共栄を図ることが企業 の使命であるとの考えから，48年10月より 3 社のほかに日本セメ ント (武甲鉱業関連) , 三菱鉱業セメント ( 菱光石灰工業関連) が加わり，トップ会合 (三社会 )をもつこととした。

その結果，各社個々に中腹から採掘する方法では鉱区間に相当 量の間隔帯を残すことになり，効率的採掘が不可能であり，環境 保全対策上万全を期すことができないので，採掘法を転換し 3 社 による山頂からの協調採掘を進めることが最良の方法であるとの 結論に達した。協調採掘の基本構想は次のとおりである。 a ) 武甲山において操業中の 3 社 4 鉱山のうちで, 山頂部で鉱区 を接している宇根鉱山，武甲鉱山，三輪鉱山生川地区 ( 以下「生 川」という)の 3 鉱山は山頂部より協調採掘を実施する。

b) 将来, 協調採掘が進行した時点で, 宇遠鉱山も参加する。

c）公害防止対策，環境保全対策等を各社が協力して実施する。

\section{$5 \cdot 3$ 基本協定畫}

基本構想をもとに協議を重ね，49年10月「協調採掘に関する基 本協定書」を締結した。その骨子は，次のとおりである。 a ）各鉱山は, 山頂からベンチカット採掘で同一レベルを確保す ることを目途として，協調採掘をする。
定の検討を行ない，更に49年 6 月，下部組織に「地質小委員会」 を設置し，残壁安定の検討に欠かせない地質調査を実施すること とした。

武甲山の残壁については, 我が国で初めての大規模な残壁とな るため, 国は「秩父地区残壁研究会」の岩盤安定計算結果につい て，49年11月「鉱山保安新技術検討会採鉱保安部会」に諮問した。 採鉱保安部会では，現地視察を含め検討を重ね，50年11月，中間 答申をした。

その結果は, 岩石強度調査の継続, 地下水に対する配慮等の条 件付きではあるが，「秩父地区残壁研究会」で検討したもので安 定であるとの答申であつた（52年度石灰石鉱業大会で発表済み）。 残壁に対する調査研究は現在も続けられ, 月 1 回開催している 「秩父地区残壁研究会」は，すでに 111 回を数える。また，協調 採掘の開始に合せ，残壁安定に関する調査研究あるいは現場にお ける調査実験観測等を推進するため，56年 3 月下部組織に「残壁 研究会ワーキンググループ」を設置した。 3 社は, 従来あり勝ち な秘密主義を打破し, 手持資料を出し合い, あるいは共同研究す ることにより, 残壁安定の調査研究を続けている。

\section{$5 \cdot 5$ 施業案}

3 社は，49年10月「武甲山協調採掘技術委員会」を発足させ, 協調採掘の具体的計画の検討を行なつた。計画は, 基本協定等を もとにして次の構想ですすめられた。

a 宇根, 武甲ならびに生川の 3 鉱山はおのおの大坑井を上げ, 山頂部からベンチカット方式により同一レベルを保ちながら協調 採掘を実施し，同時に中腹の採掘ベンチは一時休止する。

b 下盤輝緑凝灰岩側に石灰石のカバーロックを残し, 永久残壁 を形成する。

c 残壁には高さ $10 \mathrm{~m} \sim 20 \mathrm{~m}$ 毎に十分な幅を有する犬走りを設け, 直ちに緑化工事を開始する。

3 社は，以上の総合開発方式を実施することにより，地域社会 との共存共栄の実現が可能であると確信し, 山頂協調採掘に関す る施業案について折衝を開始した。

当初, 国は最終残壁の安定, 跡地の緑化, 山容の変化等に危具 の念をもち，計画の遂行は難しい状況であつたが，これらの問題 について 3 社共同で対策を講じ, 折衝を重ねた結果51年11月施業 案の認可を受けた。

採掘に関する技術的な問題については，現在も「武甲山協調採 掘技術委員会」で検討しているが，これも 111 回 (毎月 1 回開催) を数えている。

\section{6. 協 調 採 掘}

\section{$6 \cdot 1$ 生産計画}

協調採掘による年間生産量を 620 万 $\mathrm{t}$ と計画した。各社の必要 量は次のとおりである。( なお, その後の情勢変化により若干変更 


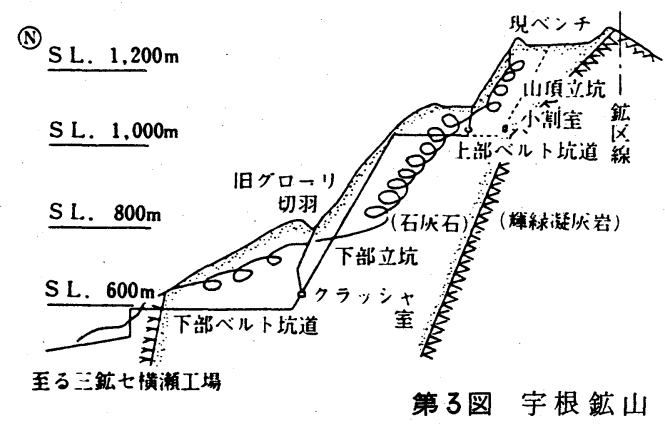

している。)

宇根 -200 万 $t /$ 年 $(16.7$ 万 $t /$ 月 $)$

武甲一 240 万 $t /$ 年 $(20.0$ 万 $t /$ 月 $)$

生川一 180 万 $\mathrm{t} /$ 年 $(15.0$ 万 $\mathrm{t} /$ 月 $)$

\section{$6 \cdot 2$ 開発計画}

宇根, 武甲, 生川の各鉱山は, 既設の坑内施設を利用し, 新た に立坑を掘り上げる

(1) 宇根 : 既設上部ベルト坑道 (標高 $1,030 \mathrm{~m}$ )を約 $40 \mathrm{~m}$ 下盤側 へ掘進し,この位置より山頂立坑 (延長 $290 \mathrm{~m}$, 傾斜 $60^{\circ}$ ) 標高 $1,300 \mathrm{~m}$ まで掘り上げる (第 3 図)。

(2) 武甲：標高 $515 \mathrm{~m}$ の既設水平坑道から約 $500 \mathrm{~m}$ 下盤側へ掘 進し破碎プラントを設置する。これより山頂立坑（延長 $720 \mathrm{~m}$ ， 傾斜 $75^{\circ}$ ) を標高 $1,290 \mathrm{~m}$ に掘り上げる (第 4 図)。

(3) 生川 : 中央グローリホールの標高 $600 \mathrm{~m}$ から下部水平坑 (延長 $380 \mathrm{~m}$ ) ，下部立坑 (延長 $340 \mathrm{~m}$ 傾斜 $75^{\circ}$ ) , 中段水平坑 (延 長 $240 \mathrm{~m}$ ), 上部立坑 (延長 $250 \mathrm{~m}$, 傾斜 $60^{\circ}$ ) を掘進し標高 1,210 $\mathrm{m}$ に掘り上げる (第 5 図)。

以上の坑内構造に付帯して，採掘場行き自動車坑道を設置する。 一方坑外では落石防止柵設置, 重機搬入路造成, 表土除去, 切羽 段取等の準備工事を行い，採掘ベンチの造成を開始する。

\section{$6 \cdot 3$ 工事工程}

協調採掘の開始時期については, 中腹ベンチ採掘が一番早く終 る生川を基準として56年10月開始を目途とした。従つて，3 鉱山 の上下作業を回避し所要年生産量 620 万 $\mathrm{t}$ を確保するためには, それまでに年産 620 万 $\mathrm{t}$ 採掘できる大きさのベンチ（約 8 万 $\mathrm{m}^{2}$ ， 標高 $1,270 \mathrm{~m}$ ) を造成する必要がある (第 6 図)。このことから工 程を決定した (第 2 表 )。

工事は各鉱山ともほぼ計画どおり進 捗し, 協調採掘開始地点の標高 1,270 $\mathrm{m}$ には予定より半年早まり，56年 3 月 に到達したので56年 4 月から協調採掘 をスタートさせた。

\section{$6 \cdot 4$ 山頂採掘作業}

協調採掘は第 7 四に示すように，鉱 区線を境界として各社独自に採掘する が，おのおの十分な打合せ，連絡をと り, ベンチを同一レベルに保ちながら 採掘する。起碎原石はおのおのの立坑 に投入する。

現在, 採掘は標高 $1,230 \sim 1,210 \mathrm{~m}$ で実施しており，ベンチ面積は約 $100,000 \mathrm{~m}^{2}$ である。なお, 山頂付近の 生川ベンチは非常に狭いので, 標高 $1,180 \mathrm{~m}$ までの範囲については武甲鉱 山が粗鉱している。
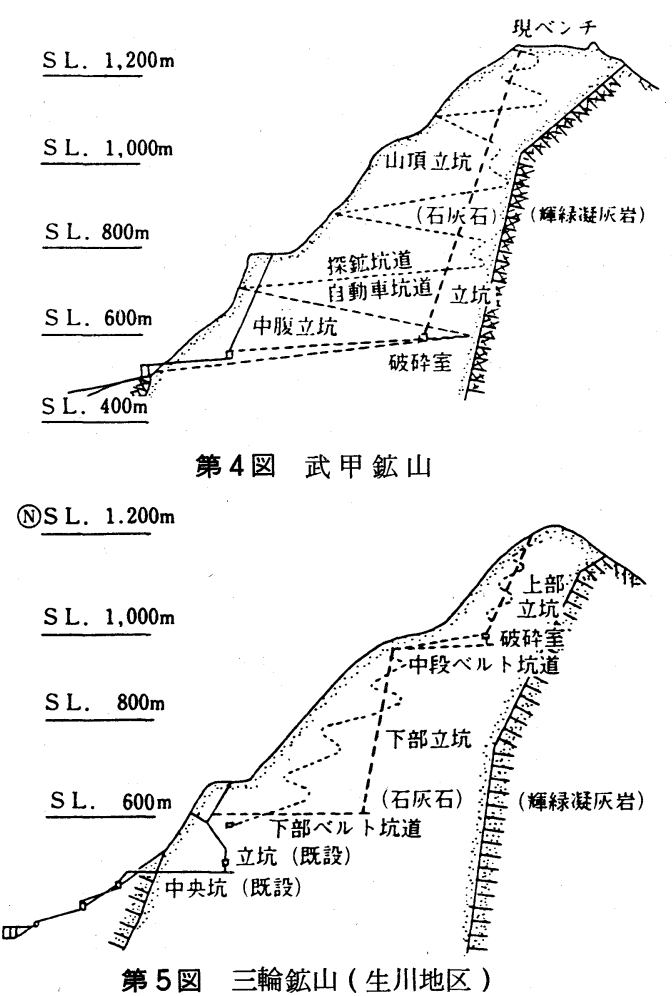

7. 協調採掘上の問題と対策

協調採掘を開始するに当り，実施した対策として，残壁並びに 施業案関係については，前述のと招りであるが，その他にも多く の問題がありおのおの 3 社で協力して解決した。そのうちの主な 事柄について以下に述べる。

\section{$7 \cdot 1$ 地元対策}

協調採掘区域の当面の関係自治体である横瀬村と土地所有者に, 協調採掘に関する計画書を提出して趣旨の説明と協力をお願いし, 49年7月承認を得た。その後, 秩父市, 県へ説明したがこれらは すべて 3 社協力して対応した。

この他, 地元に関する一般的な問題については， 3 社の総務担 当者の集りである「17日会」が当り，技術的事項については,「協 調採掘技術委員会」で検討し，逐次解決している。

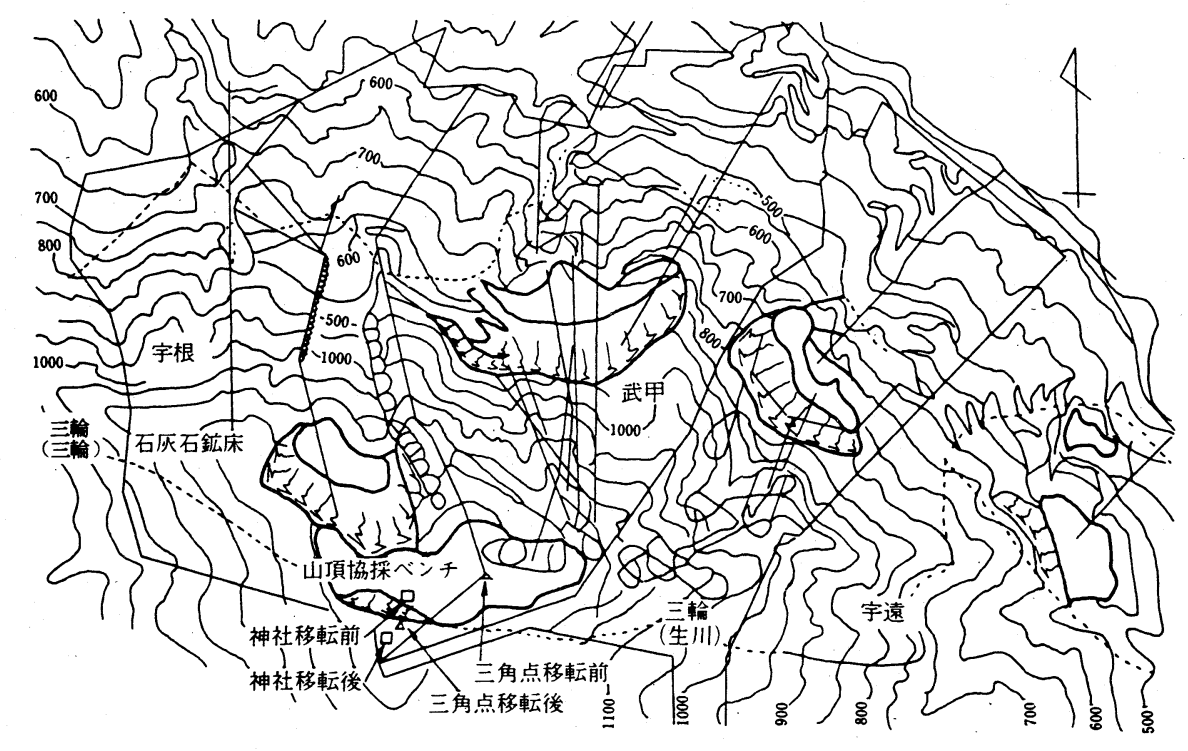

第6図，協調採掘平面困 
第 2表 協調開発工事工程表

\begin{tabular}{|c|c|c|c|c|c|c|c|c|c|c|}
\hline \multicolumn{2}{|c|}{ 名称 年次 } & 51年 & 52年 & 53年 & 54年 & 55年. & 56年 & 57年 & 58 年 & 的神考 \\
\hline \multirow{2}{*}{ 恶告 } & 現ベン千作業終了 & 20 & $\mathrm{ZWC}$ & ב"ב & 27 & $\mathrm{DZn}$ & $\left.\frac{1}{3}\right)^{9}$ & & & 凡例 \\
\hline & 立坑他開さく & & & & 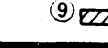 & 202 & מל2 & & & 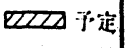 \\
\hline \multirow{3}{*}{$\begin{array}{l}\text { 武 } \\
\text { 錙 } \\
\text { 山 }\end{array}$} & 立坑他開さく & & 200000 & क्या & (6) & & & & & \\
\hline & 切 羽 段 取 & & एक्त & 2000 (12 & & & & & & \\
\hline & ベンチ造成 & & & & 7 & $\mathrm{ZWZ}$ & ه & & & \\
\hline \multirow{3}{*}{ 䐴 } & 保专林保绫設備 & & $\begin{array}{l}\text { 51年11月 } \\
\text { 施独案許可 }\end{array}$ & (4) $\frac{\mathrm{men}}{12}$ & $z^{(5)}(10)$ & & $\mathrm{SL1}, 210 \mathrm{~m}$ & $\begin{array}{l}56 \text { 年 } 4 \text { 月 } \\
\text { 協採開始 }\end{array}$ & & \\
\hline & 立坑他開さく & & & (3) & $\infty$ (5) & & & & & \\
\hline & ベン 千造战 & & & & (6) & 7 & סקרב & & & \\
\hline
\end{tabular}
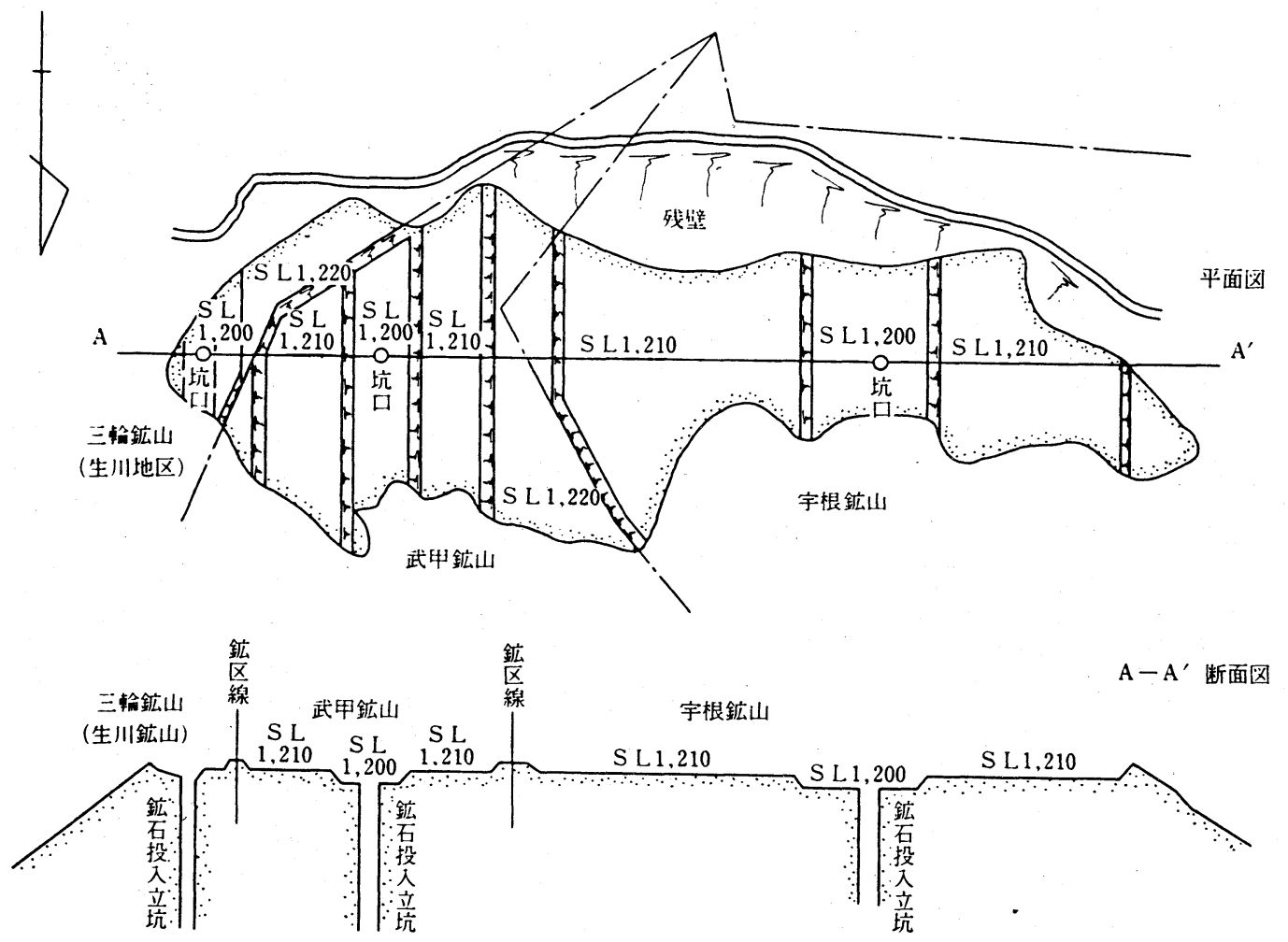

第 7 図 協調採掘規格 (一例) S L $1200 \mathrm{~m}$

\section{$7 \cdot 2$ 御茲神社の僄座}

武甲山山頂付近に鎮座する御嶽神社（祭神日本武尊 4 柱 ) の神 殿恃老朽化し，また，41年 9 月の伊勢湾台風によつて被害を受け， かねてから修復の気運があつた。

3 社としては，神社が協調採掘計画区域内にあり，移転の可否 が石灰石可採鉱量に大きな影響があつたので神社側と話し合い, 「神社境内地内で協調採掘に支障のない場所に， 3 社の負担で移 転し，修復する」ことでまとまつた。

早速, 神社造営の専門家に委嘱し, 50 年10月遷座祭を挙行し, 無事移転修復を完了した。協調採掘は神社の移転で道が開けたと 言つても過言ではなく, その後, 奥の院, お諏訪様, 雨乞神社, 白鳥神劍神社等の神様や，長寿の鐘，遭難の碑，茶店等について もそれぞれの関係者と折衝し，53年 8 月新社殿付近に移転した。

\section{$7 \cdot 3$ 武甲山資料館}

武甲山開発に反対の立場にある地元自然保護団体「武甲山を守 る会」と秩父市長, 横瀬村長並びに 3 社は定期的に郎談の場を設 け，ここで 3 社は環境保全および公害防止対策上山頂から協調採
掘を実施することが最良の方策である旨説明した。

「武甲山を守る会」からは，地元住民感情を十分考虑し，誠意 をもつて事に当つて欲しい旨の要請があり, 検討した結果, 武甲 山の山容および貴重な動植物を後世に残すため， 3 社の負担で資 料館を建設することになつた。

資料館は，武甲山が一望できる秩父市羊山公園内に54年11月完 成した。館内には, 動植物以外に地質, 採掘, 石灰石の用途等の コーナーも設けられている。運営は秩父市, 横瀬村, 自然保護団 体と 3 社による「武甲山資料保存会」で行ない，その運営費につ いては 3 社が大部分を負担している。

\section{$7 \cdot 4$ 武甲山綜合調查会}

武甲山には文化的価値のあるものが埋蔵されているとの言い伝 えもあり, 地元に開発前に発掘調査をしたいとの意向が強く, 県 から協力方の要請があつた。そこで, 県, 市, 村と 3 社で話し合 つた結果，総合調査を行なうことになつた。

これを受けて52年 3 月「武甲山綜合調査会」(会長, 横瀬村長) が発足した。調査項目は埋蔵文化財の発掘に止まらず, 動物, 植 
物, 民俗, 歴史, 写真, 気象, 地質, 建造物, 登山史, 文化等 11 分野に及び，それぞれに専門家を配置し，3 年計画で現地調査を 行ない, 現在, 資料整理並びに刊行物の原稿を執筆中である。こ れらの費用の大部分は 3 社で負担している。

\section{$7 \cdot 5$ 保安林解除}

宇根鉱山，三輪鉱山鉱区内の石灰石が賦存する尾根部南側に水 源涵養保安林，および土砂流出防備保安林がある。林野庁からは， 当地区は一級保安林であり解除しないのが建て前であり，仮りに 解除する場合, 公益性が高いという条件が必要であるとして, 前 途多難を示唆された。

3 社は, 相協力して, 50 年12月から秩父市, 県, 林野庁と折衝 して, 保安林解除の必要性を説明した。その結果, 51年11月, 解 除申請区の大部分の所有者で, かつ行政当事者でもある秩父市長 の同意を得, 申請区域（2区域）は52年10月～11月におのおの解 除予定保安林となつた。

\section{$7 \cdot 6$ 三角点の移設}

武甲山山頂標高 $1,336 \mathrm{~m}$ に二等三角点が設置されており，協調 採掘計画区域の始発部中央に位置していたので，移転は必須の条 件であつた。

移転について国土地理院に申し入れ折衝した結果，52年 2 月， 新御獄神社裏側の標高 $1,295 \mathrm{~m}$ の地点に移転することができた。

\section{$7 \cdot 7$ 採掘跡地の緑化}

46 年, 環境庁が新設され, 環境問題がクローズフップした。 東京通産局は時流を受けて, 企業と学識経験者をまじえた「秩 父多摩地区石灰石鉱山緑化対策研究委員会」を発足させ，緑化問 題の検討に乗り出した ( 47 年 7 月)。

当委員会は，49年 6 月「石灰石鉱山緑化対策研究委員会」とな り, 学識経験者の陣容も強化された。各鉱山にはテストベンチを 造成し, 調査研究を続け, 52 年 3 月緑化暫定基準がつくられた。 その後も研究が続けられ，57年10月「石灰石採掘跡地緑化技術指 針」が作成された。

3 社がこの研究委員会とともに緑の復元に力を注いでいること は，地元の住民に好印象を与えている。

\section{8. 協調採掘の効果}

（1）可採鉱量の確保 鉱区間に間隔帯を残さないので，石灰 石を無䭾なく効率よく採掘できる。当面協調採掘する宇根, 武甲, 生川の 3 鉱区の可採鉱量は約 7.3 億七であるが, これを単独で採掘し た場合, 約 5 億 $\mathrm{t}$ に減少する。また, 神社等の移転ができなかつた 場合はもつと減少するので, 今回の 3 社協調採掘の効果は非常に 大きい。これにより，武甲山百年の大計が可能となり，各社とも
安定供給の見通しがついた。

（2）安全確保隣接鉱山ベンチとの上下関係がなくなり，ま た，鉱区境の残壁がなくなつたことにより，災害発生の危険性は 著しく減少する。

（3）治水対策 集中豪雨時においても広いベンチの有効活用 により計画的な集水, 沈砂が可能であり, 治水対策も極めて有効 である。

（4）自然環境対策 3 社協同で計画的な緑化作業が実施でき るので, 自然環境保持に有効である。

(5) 施設の共同利用鉱山道路, 施設, 用地等の共同利用が 可能となり経済的である。

（6）地元対策地元に対しては自然環境保全, 公害対策等に ついて 3 社で同一歩調により対応できるので, 地元住民との話し 合いに撂敕をきたすことなく前向きに対応でき，地域社会との共 存共栄の実現が可能である。

\section{9. 結言}

武甲山々頂から協調採掘することは，我々技術者の夢であり， それが多くの人々の努力により現実のものとなつた。ライバル関 係にある 3 社が協力体制を敷き, また, 地域社会との調和をはか り，協調採掘を実現したことは資源の少ない日本で先鞭をつけた 者として喜びを感ずる。

この協調採掘を武甲山の採掘が終る 100 年後まで続けるよう， 我々は次の世代に引き継ぐ考えであるが，今後の大きな問題とし て残壁安定と緑化がある。

残壁安定については，現在調査研究しながら発生しつつある残 壁の安定設計をすすめているが，この残壁が安定するためには今 から緻密な設計が必要であり, 現在の調査研究の重大さを痛感し ている。

また, 武甲山の緑化は多くの人々の要望であり, 早期緑化が期 待されている。しかし，残壁傾斜が急で，しかも岩肌に早期に緑 化することは自然の摂理に反し，至難の技である。我々は自然の 営みで現在の状態に戻すのに要する長い時間を少しでも短縮し， 何日の日か, 緑の武甲山が浭ることを期待し緑化の研究を続けて いる。このため残壁には 3 社共用の管理道路を造成し, 草木の育 成に努め少しでも早く緑に戻すようにする。

最後に，協調採掘計画の初めから献身的なご指導を戴いている 東京大学名誉教授下村弥太郎先生に深く感謝の意を表し，またい ろいろ御指導して下された東京大学, 京都大学, 早稲田大学, 熊 本大学, 東北大学, その他多くの諸先生方や関係官庁等の皆様方に 御礼を申し上げるとともに，今後の御指導をお願い致す次第である。

\title{
On the Co-Operative Development of Limestone Mines in Mt. Buko by Three Companies
}

\author{
by Ken YAGI, Wataru MORITA, Hiroshi SAITO and Eiichi KATO
}

Mt. Buko, elevation $1,336 \mathrm{~m}$ (now 1,304m), is located at the western part of Saitama Prefecture near Tokyo, and the majority of its mass consist of limestone. The mountain is well-known for its limestone production as well as for its scenic beauty and as being a place of historical interest.

Three mining companies have concessions for mining limestone, and four mines are now in operation. The three mining companies are Chichibu Cement Co., Ltd., Buko Mining Company of Nihon Cement Group, and Ryoko Lime Industries, a part of the Mitsubishi Mining and Cement group.

Heretofore, all of these companies were mining independently, without co-operation, within their respective mining areas, which start from the mid-slopes of the mountain. However, 10 years ago the co-operative development project was envisaged by the companies in order to realize efficient and rational development.

In carrying out this project, technological studies, environmental assessments, and negotiations were made for the purpose of finding solutions to possible hindering problems. 